\title{
IFRS implementation in Romania Certified Accountants perspective
}

\author{
Dragos Andrei STOICA \\ Bucharest University of Economic Studies, Bucharest, Romania \\ dragos.stoica@ase.ro \\ Marius Eugen ROGOZ \\ Bucharest University of Economic Studies, Bucharest, Romania \\ marius.rogoz@cig.ase.ro
}

\begin{abstract}
This study aims to investigate the opinions of certified accountants in Romania on the implementation of the IAS/IFRS (International Accounting Standards/International Financial Reporting Standards) in an emergent country that has a short to medium experience in adopting and implementing the standards.
\end{abstract}

Keywords: IAS, IFRS, emerging economy, standards, accounting, certified accountant.

\section{Introduction}

According to Littleton (1933) "accounting is relative and progressive. The phenomena that shape its core are constantly changing. Older methods are becoming less effective in the face of change; previous ideas become irrelevant in the face of new problems. Thus, the surrounding conditions generate fresh ideas and stimulate the ingenious to design new methods. When such ideas and methods prove to be successful, only then does the change around them begin to take shape - The result we call progress".

Accounting is often correlated with the attribute of development that comes from creativity. The following is a description of progress: "An advance towards something better or towards a greater development" (Chambers English Dictionary, 1996). The two most critical aspects of development are illustrated in this definition. First and foremost, it is a complex concept: development necessitates some degree of transition. However, improvement alone isn't enough: it has to be for the better. Progress can be described as a more or less continuous process of change, as well as progress toward a particular goal or end (Napier, 2001).

Farmers of the time used clay to indicate the scale of agricultural crops, and the first historical documents relating to accounting appeared between 8000 and $1000 \mathrm{BC}$. The need for small traders and producers to keep track of their earnings has grown as trade has advanced (Carnegie and Napier, 1996). Consequently, goods were manufactured in guilds during the Middle Ages, which favored the expansion of trade and the collection of products sold. Some retailers decided to sell such goods at a later date and collect their value over a period of time instead of collecting coins on the spot at the time of the sale.

The control of industry and careers faces various challenges as a result of globalization (Mennicken, 2008; Samsonova, 2013; Caramanis et al., 2015). Globalization has resulted in the adoption of international standards and models that have been transposed as developments in a local context in the field of accounting. Accounting developments, in general, are improvements in the laws that cause or are intended to cause major changes in practice (Mennicken, 2008). Changes brought on by these developments are now being studied (Mennicken, 2008; Zijl \& 
Maroun, 2016) and, in particular, local contexts, with significant changes in the economic, political and social environment, provide a desirable and fascinating space for in-depth investigation (Albu et al., 2014; Mennicken, 2008). Gallhofer and Haslam (2006) saw globalization as "a political, economic, technological and cultural phenomenon ... especially characterized by the growth and speed of suprastatism, supranationalism or supraterritoriality" (p. 905).

The globalization process has achieved an unparalleled degree of growth with the passing of the new millennium (Godfrey and Chalmers, 2007; Fonseca and Azevedo, 2020). Technological advances and the rapid growth of information transmission systems have played a significant role in the radical transformation of business organization and development (Busu et al., 2020). Simultaneously, they have seen not only a rise in local capability, but also a major geographical expansion. The need to standardize financial reporting structures has been a major consequence of globalization.

Institutional factors are primarily analyzed by institutionalist theory, which focuses on national and organizational factors (Jamali and Neville, 2011; Gavurova et al., 2020). Translating and adapting new approaches and strategies so that they are adopted and used in practice is crucial to implementation success. (Thornton and Ocasio, 2008). Previous research into the role of institutional factors in adopting technologies has looked at factors that affect IFRS enforcement at the organizational level, for example.(Maroun and Zijl, 2016), the effect of political factors on the formation and activity of the supervisory body occupation (Caramanis et al., 2015) or the importance of non-financial reporting in the evolution of a business (Gușe et al., 2016). International Financial Reporting Standards (IFRS) are a set of general principles used in the preparation of an entity's financial statements, with the aim of achieving greater consistency of results, increasing the level of transparency and, at the same time, ensuring the comparability of information (IASB, 2010).

\section{Literature review}

The IASB defines the guidelines, which serve as a reference for businesses performing and reporting business transactions. IASs were issued between 1973 and 2001 by the International Accounting Standards Committee (IASC). The IASB adopted all IAS standards in April 2001 and continued to improve them after that. The current norms, however, are known as IFRS. Current IAS standards remain in force until they are replaced or modified by issuing new IFRSs, even if new IAS standards are no longer published. More than a hundred states either mandate or permit the use of IFRS, or have a policy of convergence with them. The International Financial Reporting Standards (IFRS) were developed as a popular global business language to ensure that a company's financial reports are understandable and comparable around the world. IFRSs are particularly relevant for companies with a global network of relationships. Simultaneously, they are steadily replacing a number of national accounting principles.

The International Accounting Standards Board (IASB) published IAS from 1973 to 2001. The new IASB took over the IASC's International Accounting Standards setting on April 1, 2001. The new Board accepted the IAS and the Standing Committee on Interpretation's current principles at its first meeting (SIC). The International Accounting Standards Board (IASB) has continued to develop IFRS -based standards.

The goal of creating a single set of accounting standards that can be used globally to minimize the gaps between national GAAP and IFRS is known as convergence of accounting standards. Convergence is also occurring in other nations, with all of the world's major economies 
preparing to implement or converge on the International Financial Reporting Standards (IFRS) in the near future.

More than a hundred countries have adopted or declared their intention to implement or even follow international accounting principles at this time. The European Parliament passed a regulation on July 19, 2002, requiring IFRS in consolidated accounts of listed firms, including banks and insurance companies, starting in 2005. The International Accounting Standards Board (IASB) and the Financial Accounting Standards Board (FASB) jointly released a memorandum on February 27, 2006, confirming the two bodies' mutual goal of establishing high-quality universal accounting standards for use on international stock exchanges.

The IASB (2010) describes the importance of the details provided, as well as its correct representation, as the key characteristics of financial statement standards. The two concepts listed above are described as follows by Palea (2013). To begin with, financial data is important as it helps the entity's management or stakeholders to make and execute effective decisions and actions for the company's benefit. Second, the accuracy of accounting data to accurately reflect current economic reality is referred to as fair representation of accounting data. The adoption of standards by developing states, according to Albu et al. (2011), is a way for them to gain greater reputation and legitimacy in foreign markets. For many emerging economies, IFRS has been seen as part of the "logic and realities of globalization to take part in the wealth enjoyed by developed nations" (Albu et al., 2014).

The key users and beneficiaries of the standards are specified by the IASB (2010). As a consequence, the standards' primary aim is to provide relevant information to investors, creditors, and other stakeholders so that they can make the best decisions possible (regarding the allocation of resources). Palea (2013) begins with the IAS/IFRS key objective and defines the value of investors as being at the highest level.. Thus, Palea (2013) argues that investors become the most significant consumers of accounting information because they fund the capital entity and cannot usually request internal information, so financial reports are the primary source of financial information that underpins their decisions.

Institutional factors such as geography, culture, economic growth, taxation, and the education system, according to Nobes (1998), regulate the setting under which accounting systems grow.

Zehri and Chouaibi (2013) claimed that community, economic growth, capital market opening, level of education, openness to the outside world, the legislative framework, and politics are some of the institutional factors that affect the adoption and implementation of standards. Following that, I'll offer a short rundown of the theories they come up with as a result of their research.

Approaching a perspective of a network of actors regarding the implementation of IFRS in Romania, we can assume that the action, in this case, is understood as mediation, binding or modeling of organizational practices. Latour (1996) considers that a network of people and nonpeople makes up reality. The activities of skilled accountants, auditors, and consultants, the stock sector, the political and legislative sphere, consumers (investors, lenders, or creditors), the financial supervisory authority, and other actors are all regarded in this section as the actors that shape the economic reality. It is important to understand not only the relationships between the various types of actors, but also the way in which these networks of actors are interconnected, in order to complete the picture of IFRS application by companies.

Economic history reveals that the differences between Romania and Western countries have developed over time (Murgescu, 2010), and closing them is a major challenge for Romanian 
society. Until 1947, as part of Romania's modernization and westernization, capitalist modes of economic organization and accounting were introduced from the West.

Romania is a country in Europe's EEA zone, where the interests of three great neighboring empires collided: Ottoman, Russian, and Austrian; and where capitalism and the industrial revolution were the key drivers of economic growth. However, the attribution of capitalist economic and industrial growth created the conditions for the establishment of the modern Romanian state, which began with the Union of Romanian Principalities in 1859, followed by Moldavia and Wallachia in 1859, and the other Romanian province, Transylvania, which was absorbed into Austria. Hungary until the beginning of the 20th century, when the Great Union took place with Romania in 1918. Romania is a developing country and there is a strong consensus that it faces a number of challenges in applying IFRS (Feleagă and Feleagă, 2016; Albu et al., 2011; Albu et al., 2020).

The dense and complex political network of actors developed in Romania during the postcommunist period helps to strengthen the relevance of the national case for this research. Nobes (2008) proposes that European countries be split into two categories. Although Romania does not appear in this grouping, Istrate (2014) claims that it belongs in group two (class B), alongside all other ex-communist countries; the key characteristics of this group are a less developed financial market, government control, and a more revenue-oriented tax system. We would assume the implementation of IFRS to have a substantial effect on the accounting figures under these circumstances. However, multiple factors had to be considered during the 2012 transition to IFRS, which undoubtedly contributed to some anticipation of some of the particular IFRS regulations.

Accounting regulations were introduced in 2005 to fulfill the requirements of Romania's EU accession, which was due to begin on January 1, 2007. According to them, since 2006, the companies have been forced to apply accounting regulations for individual financial statements in compliance with European directives. Only the consolidated financial statements of publicly traded companies and banks were required to use IFRSs. While the use of IFRS in individual financial statements was only available on a voluntary basis for a few businesses, and only in a second collection of financial statements in addition to those prepared in compliance with local legislation and European directives. As a result, individual financial statements prepared in accordance with IFRS are obtained by sending financial statements prepared in accordance with European directives and are only served to users other than state institutions that need details (Ionașcu et al., 2014).

In 2012, another phase of the expansion of the adoption of IFRS Romania took place, which aimed to introduce IFRS in the individual financial statements of entities on a regulated market and eliminate double reporting for these companies (Albu et al., 2011; Albu et al., 2020). The need to comply with international practice of encouraging accountability and comparability of financial statements, given the state's interest in shielding itself from potential foreign capital outflows through exploiting discrepancies in treatments, was one of the motivations provided by accounting regulators regarding the extension of the mandatory implementation of IFRS. Accounting used by multinational firms, as well as international organizations' recommendations for the application of international financial reporting standards, such as the World Bank and the International Monetary Fund (Ionașcu et al., 2014; Albu et al., 2011; Albu et al., 2020).

In addition, as required by IFRS, listed Romanian entities that apply IFRS for the first time in individual financial statements must provide reliable and comparable details for prior years (Feleagă and Feleagă, 2016). As a result, the financial statement as of December 31, 2012 incorporates comparable data for the two financial years preceding the reporting period (2011 and 2010). 
The Romanian accounting profession progressively became familiar with the principles of IFRS as a result of these changes. The transition to international standards, on the other hand, has not been straightforward. IFRS adoption has been aided by a variety of players, including members of international organisations, parent corporations, the government, and professionals. (Albu and Albu, 2012; Albu et al., 2011; Albu et al., 2020).

\section{Methodology}

Although big 4 firms are expected to audit a large portion of listed companies and subsidiaries, the Romanian market is unique in that non-big 4 firms play a significant role. For example, Grosu et al. (2015) finds that over $65 \%$ of the listed companies on the BSE analysed (63 companies have made the sample out of a total of 87 , which accounts to $72 \%$ of the total number of companies listed on BSE) are audited by non-big 4 auditors. Romania's implementation of IAS/IFRS has been challenging, and it has only been completed in part. The main players on the international audit market (at the time, the Big 5) had a major input on the policy making and implementation of IAS/IFRS during this process, which began in the early 1990s (Albu et al., 2011; Nurunnabi, 2015). Auditors also provided training and consulting services for IAS/IFRS application to businesses (Albu et al., 2011; Nurunnabi, 2015), thus making them a very important set of actors for this study.

Despite the figures presented above, the BIG4 party appears to have a stable market share and has consistently shown that it has more experience with the Standards (than their counterparts - non-big4 audit firms), and many of their employees are certified public accountants.

Our research was based on a survey, which consisted of 28 questions, divided into 2 sections (S1. General information about the respondents, S2. Specific questions about IFRS). For the S2 section the answers where gathered using a Likert scale (where 1 - Strongly disagree, 5 - Strongly agree).

The survey was sent to public certified accountants from Romania. The response rate was approximately $44.7 \%$ (62 respondents) and the survey was opened through the months of June and July of 2020.

\section{Results and conclusions}

\section{Section 1 -demographic data}

In this section we have gathered the general information regarding our respondents. Thus, we have 62 respondents, who have all attained the qualification of certified accountants. We have a perfect split regarding the gender of the respondents, with 31 being women and 31 being male.

In regards to their age, 3\% are 21 and under, almost 34\% are between the ages of 22 and 25 , and the vast majority $(61.94 \%)$ are over 25 years old.

Another important aspect that we have focused on was that of their educational background. From the results we can observe that $14.52 \%$ have at least a bachelor degree, 53.23\% have at least a master's degree, $30.65 \%$ have a doctorate degree and just only $1.61 \%$ have a post-doctorate degree.

Another point of emphasis was the respondents' experience. Thus, we can see from the table below that the majority of respondents are working in Romanian owned companies (43.55\%), $25.81 \%$ are working in a company from the BIG4 group, and $29.03 \%$ are working in a subsidiary of a multinational company.

In regards to their actual working experience in the field of accounting, we can observe that most of the respondents have an experience of more than 1 year $(85.49 \%)$, with $30.65 \%$ having 
an experience of more than 3 years. If we look at the respondents experience with IFRS, we can see a consistent trend between working experience and experience with IFRS. $40.32 \%$ of the respondents have evaluated their familiarity with IFRS (on a scale from 1 to 5) by a grade of 4, $41.94 \%$ have evaluated it with a grade of 5 and the rest $(17.74 \%)$ have evaluated their knowledge on the matter with a grade of 3 .

Through our survey we have also made inquiries about the department in which the respondents work in. $40.32 \%$ of the respondents work in the Accounting department, $35.48 \%$ work in the Audit department, and the rest of the respondents work in the financial department.

\section{Section 2 - opinions on IFRS}

Table 1. Opinions on the implementation of IAS/IFRS in Romania

\begin{tabular}{|c|c|c|c|c|}
\hline No. & Question & Median & Mean & Stdev \\
\hline \multirow{4}{*}{1} & $\begin{array}{l}\text { Estimate on a scale of } 1 \text { (not at all) to } 5 \text { (to a very large extent) the extent to } \\
\text { which you believe that the following actions are considered to be an obstacle } \\
\text { to the implementation of IFRS }\end{array}$ & & & \\
\hline & a) IFRS are very complicated & 4.05 & 4.00 & 0.81 \\
\hline & b) IFRS covers a broad dimension of accounting & 3.37 & 4.00 & 0.88 \\
\hline & c) IFRSs are constantly changing & 3.53 & 4.00 & 0.80 \\
\hline \multirow{6}{*}{2} & $\begin{array}{l}\text { Estimate on a scale of } 1 \text { (not at all) to } 5 \text { (to a very large extent) the extent to } \\
\text { which you believe the following measures contribute to a better } \\
\text { implementation of IFRS }\end{array}$ & & & \\
\hline & a) Convergence of tax legislation with IFRS principles & 3.98 & 4.0 & 0.92 \\
\hline & $\begin{array}{l}\text { b) Cooperation of all parties involved (eg companies, audit firms, state } \\
\text { institutions, etc.) }\end{array}$ & 4.18 & 4.00 & 0.68 \\
\hline & c) Several guidelines on the application of IFRS & 4.34 & 4.00 & 0.72 \\
\hline & d) Modification of the Romanian Chart of Accounts & 3.63 & 4.00 & 1.07 \\
\hline & e) Increasing the quality of audit services & 3.95 & 4.00 & 1.04 \\
\hline \multirow{8}{*}{3} & $\begin{array}{l}\text { Rate your agreement on the following statements about IFRS on a scale of } 1 \\
\text { (not at all) to } 5 \text { (to a very large extent): }\end{array}$ & & & \\
\hline & a) IFRS provides users with more reliable information on the market & 4.24 & 4.00 & 0.84 \\
\hline & $\begin{array}{l}\text { b) IFRSs provide information on the market with a higher level of } \\
\text { transparency }\end{array}$ & 4.13 & 4.00 & 0.75 \\
\hline & c) IFRS contributes to the efficiency of capital markets & 4.03 & 4.00 & 0.93 \\
\hline & $\begin{array}{l}\text { d) IFRS contributes to the increase in demand for shares from foreign } \\
\text { investors }\end{array}$ & 4.21 & 4.00 & 0.72 \\
\hline & $\begin{array}{l}\text { e) IFRS limits managers' ability to manipulate financial statements and } \\
\text { mislead investors }\end{array}$ & 3.89 & 4.00 & 0.95 \\
\hline & f) IFRS increases earnings volatility & 3.31 & 3.00 & 0.94 \\
\hline & g) IFRS increases stock price volatility & 3.32 & 3.00 & 0.91 \\
\hline \multirow{4}{*}{4} & $\begin{array}{l}\text { Estimate on a scale from } 1 \text { (not at all) to } 5 \text { (to a very large extent) your } \\
\text { agreement with the following statements about the adoption of IFRS in } \\
\text { Romania: }\end{array}$ & & & \\
\hline & $\begin{array}{l}\text { a) For the proper implementation of IFRS it is necessary for the entities to } \\
\text { recruit new qualified personnel and to invest in the preparation and training } \\
\text { of the existing one. }\end{array}$ & 4.29 & 4.00 & 0.75 \\
\hline & $\begin{array}{l}\text { b) For the proper implementation of IFRS, it is necessary to upgrade the } \\
\text { information systems }\end{array}$ & 4.16 & 4.00 & 0.88 \\
\hline & $\begin{array}{l}\text { c) The initial adoption (2007) of IFRS in Romania was made without proper } \\
\text { preparation by the competent authorities }\end{array}$ & 3.84 & 4.00 & 0.99 \\
\hline
\end{tabular}




\begin{tabular}{|c|c|c|c|c|}
\hline No. & Question & Median & Mean & Stdev \\
\hline & $\begin{array}{l}\text { d) Mandatory adoption of IFRS should be limited to consolidated financial } \\
\text { statements and should not extend to individual financial statements }\end{array}$ & 2.94 & 3.00 & 0.88 \\
\hline & $\begin{array}{l}\text { e) The implementation of IFRS by listed companies is a difficult process, } \\
\text { which if not done properly, can lead to delisting of the company }\end{array}$ & 3.74 & 4.00 & 1.05 \\
\hline & f) IFRS produces benefits especially for entities operating outside Romania & 4.05 & 4.00 & 0.75 \\
\hline & g) The costs of implementing IFRS often outweigh the benefits & 3.66 & 4.00 & 1.15 \\
\hline 5 & $\begin{array}{l}\text { Estimate on a scale from } 1 \text { (not at all) to } 5 \text { (to a very large extent) your } \\
\text { agreement with the statement: The implementation of IFRS rules in Romania } \\
\text { has been done in a manner comparable to the same process in other European } \\
\text { Union countries. }\end{array}$ & 2.98 & 3.00 & 0.81 \\
\hline \multirow{6}{*}{6} & $\begin{array}{l}\text { In the local context, to what extent do you consider that the following } \\
\text { institutional factors influence the level and quality of IFRS reporting: }\end{array}$ & & & \\
\hline & a) Different professional reasoning in applying IFRS & 4.05 & 4.00 & 0.86 \\
\hline & b) Connecting accounting to taxation & 4.05 & 4.00 & 0.77 \\
\hline & c) Lack of long-term employee experience in applying IFRS & 4.03 & 4.00 & 0.76 \\
\hline & d) The quality of the financial audit & 3.87 & 4.00 & 1.05 \\
\hline & $\begin{array}{l}\text { e) The attitude of managers towards risk and uncertainty in carrying out } \\
\text { accounting evaluations }\end{array}$ & 4.00 & 4.00 & 0.96 \\
\hline
\end{tabular}

Source: Authors' own research.

As we can observe from the table above, a vast majority of the respondents perceive IAS/IFRS as being complicated. Also the respondents agree with the hypothesis that IAS/IFRS cover a broad dimension of accounting and also that they are continuously changing.

In regards to a better implementation of the standards, the respondents' opinion is that the main factors are: communication (between al the actors involved - state, companies and financial entities and institutions), convergence (to the Romanian tax legislation), continuous adaptation of the Romanian chart of accounts and the quality of the audit services.

The respondents find that IAS/IFRS provide more reliable information in the financial statements, a greater level of transparency of the financial statements, the efficiency of capital markets and the attraction of foreign investors. On the other side of the spectrum, the respondents don't preponderantly agree with the statements that: IFRS limits managers' ability to manipulate financial statements and mislead investors, IFRS increase earnings volatility or that the implementation of IFRS increases stock price volatility.

There is a strong consensus amongst the respondents that for the proper implementation of IFRS it is necessary for the entities to recruit new qualified personnel and to invest in the preparation and training of the existing one. Also, they agree with the fact that there needs to be an upgrade to the informational systems of entities.

The limitation of the adoption to IFRS to only the consolidated statements is not a popular opinion and it is ranked the lowest in the table by the respondents. Over $52 \%$ of the respondents appreciate that the implementation of IFRS in Romania was a difficult process, which if not done properly, can lead to delisting of the company. Also, over $62 \%$ of the respondents belive that IFRS produces benefits especially for entities operating outside Romania.

For the proposed hypothesis that the implementation of IFRS rules in Romania has been done in a manner comparable to the same process in other European Union countries, over 84\% of the respondents appreciated that is accurate or very accurate. 
As it pertains to the institutional factors that influence the level and quality of IFRS reporting, the respondents classification in order of importance is as follows:

1. Different professional reasoning in applying IFRS;

2. Connecting accounting to taxation;

3. Lack of long-term employee experience in applying IFRS;

4. The attitude of managers towards risk and uncertainty in carrying out accounting evaluations;

5. The quality of the financial audit.

Although we can observe many benefits for the implementation of IFRS in Romania, in the opinion of the respondents there are certain drawbacks. The two main obstacles that were identified are the cost implied by the companies that wish to start implementing the Standards, and also the differences between IFRS and RAS, which entails time and resources to ensure a good level of compliance.

Through our paper we've managed to meet the goals we set at the beginning of this research. The study was conducted on a sample of 62 people, directly related to the audit and accounting field, and the response rate was $44.7 \%$, i.e. 62 individuals. We analysed the literature in order to be able to put into context the familiarity the Romanian professionals have with the IFRS.

\section{References}

Albu, N., Albu, C. N., Bunea, Ş., Calu, D. A., \& Girbina, M. M. (2011). A story about IAS/IFRS implementation in Romania. Journal of Accounting in Emerging Economies.

Albu, C. N., Albu, N., \& Alexander, D. (2014). When global accounting standards meet the local context - Insights from an emerging economy, Critical Perspectives on Accounting, 25(6), 489-510.

Albu, N., Albu, C. N., \& Gray, S. J. (2020, July). Institutional factors and the impact of international financial reporting standards: the Central and Eastern European experience. In Accounting Forum, 44(3), 184-214. Routledge.

Busu, M., Vargas, M.V., Gherasim, I.A. (2020), "An analysis of the economic performances of the retail companies in Romania”, Management \& Marketing. Challenges for the Knowledge Society, 15(1), 125-133, DOI: 10.2478/mmcks-2020-0008.

Caramanis, C., Dedoulis, E., \& Leventis, S. (2015). Transplanting Anglo-American accounting oversight boards to a diverse institutional context. Accounting, Organizations and Society, 42, 12-31, https://doi.org/10.1016/j.aos.2015.01.001.

Carnegie, G. D., \& Napier, C. J. (1996). Critical and interpretive histories: insights into accounting's present and future through its past, Accounting, Auditing \& Accountability Journal.

Dumitru, M., \& Guse, R. G. (2016). Asigurarea rapoartelor integrate: situatia actuala, Audit Financiar, 14(2), 172.

Feleagă, L., \& Feleagă, N. (2016). Romania. Shifting to IFRS: The Case of Romania. In IFRS in a Global World, 393-404, Springer, Cham.

Fonseca, L., and Azevedo, A. (2020). "COVID- 19: outcomes for Global Supply Chains", Management \& Marketing. Challenges for the Knowledge Society, Vol. 15, No. Special Issue, 424-438, DOI: 10.2478/mmcks-2020-0025.

Gallhofer, S., \& Haslam, J. (2006). The accounting - globalisation interrelation: An overview with some reflections on the neglected dimension of emancipatory potentiality, Critical Perspectives on Accounting, 17(7), 903-934. 
Gavurova, B., Cepel, M., Belas, J., and Dvorsky, J. (2020). "Strategic Management in SMEs and Its Significance for Enhancing the Competitiveness in the V4 Countries - A Comparative Analysis", Management \& Marketing. Challenges for the Knowledge Society, 15(4), 557-569, DOI: 10.2478/mmcks-2020-0032.

Godfrey, J. M., \& Chalmers, K. (Eds.). (2007). Globalisation of accounting standards. Edward Elgar Publishing.

Grosu, M., Robu, I.B., Istrate, C. (2015). Exploratory Study Regarding The Impact of IFRS on the Audit Opinion in the Case of Romanian Listed Companies. Audit Financiar 13(127).

Ionascu, M., Ionascu, I., Sacarin, M., \& Minu, M. (2014). IFRS adoption in developing countries: the case of Romania. Accounting and Management Information Systems, 13(2), 311.

Istrate, C. (2014). Impact of IFRS on the accounting numbers of Romanian listed companies. Accounting and Management Information Systems, 13(3), 466.

Jamali, D., \& Neville, B. (2011). Convergence versus divergence of CSR in developing countries: An embedded multi-layered institutional lens. Journal of Business Ethics, 102(4), 599-621.

Latour, B. (1996). On actor-network theory: A few clarifications. Soziale welt, 369-381.

Littleton, J. T. (1933). Critical temperatures in silicate glasses. Industrial \& Engineering Chemistry, 25(7), 748-755.

Maroun, W., \& Van Zijl, W. (2016). Isomorphism and resistance in implementing IFRS 10 and IFRS 12. The British Accounting Review, 48(2), 220-239.

Mennicken, A. (2008). Connecting worlds: The translation of international auditing standards into post-Soviet audit practice. Accounting, organizations and society, 33(4-5), 384-414.

Murgescu, D. (2010). The Influence of the Global Economic Crisis on Regional Differences in Romania, Public Administration in Times of Crisis, Presented papers from the $18^{\text {th }}$ NISPAcee Annual.

Napier, C. J. (2001). Accounting history and accounting progress. Accounting history, 6(2), 7-31.

Nobes, C. (1998). Towards a general model of the reasons for international differences in financial reporting. Abacus, 34(2), 162-187.

Nobes, C. (2008). Accounting classification in the IFRS era. Australian Accounting Review, 18(3), 191-198.

Nurunnabi, M. (2015). The impact of cultural factors on the implementation of global accounting standards (IFRS) in a developing country. Advances in Accounting, 31(1), 136-149.

Palea, V. (2013). IAS/IFRS and financial reporting quality: Lessons from the European experience, China Journal of Accounting Research, 6(4), 247-263.

Robinson, M., \& Davidson, G. W. (1996). Chambers $21^{\text {st }}$ century dictionary. Edinburgh, Chambers.

Samsonova-Taddei, A. (2013). Social relations and the differential local impact of global standards: The case of international standards on auditing, Abacus, 49(4), 506-538.

Thornton, P. H., \& Ocasio, W. (2008). Institutional logics. The Sage handbook of organizational institutionalism, 840(2008), 99-128.

Zehri, F., \& Chouaibi, J. (2013). Adoption determinants of the International Accounting Standards IAS/IFRS by the developing countries, Journal of Economics Finance and Administrative Science, 18(35), 56-62. 